American Journal of Applied Sciences 9 (10): 1577-1582, 2012

ISSN 1546-9239

(C) 2012 Science Publication

\title{
Ecofriendly and Simplified Synthetic Route for Polysulfone-based Solid-State Alkaline Electrolyte Membrane
}

\author{
Nittaya Pantamas, Chutharat Khonkeng, \\ Samroeng Krachodnok and Aphiruk Chaisena \\ Department of Chemistry and Center for Innovation in Chemistry, \\ Faculty of Science, Lampang Rajabhat University, Lampang 52100, Thailand
}

\begin{abstract}
Problem statement: Recently the alkaline system for fuel cell enhance their presence because of possibility of no-precious-metal catalyst and low over potential at cathode reaction. The anion exchange membrane for alkaline membrane fuel cell should be a key technology in order to achieve the practical performance as fuel cells. Alkaline anion exchange membranes of high ionic conductivities are made from polysulfone by adding a chloromethyl pendant group to the polysulfone, follow by reacting the chloromethyl group with amine to form quarternary ammonium pendant groups which act as the counter ion for hydroxide anion. Chloromethyl methyl ether, N,N-dimethylformamide and methanol are commonly used as agent for providing excellent conversions, but they are now considered to be carcinogenic. To avoid the use of such hazardous materials, in our work we used paraformaldehyde, chlorotrimethylsilane, N-methylpyrrolidone and ethanol as agent for providing conversion. Approach: Polysulfone (PS) was chloromethylated using chlorotrimethylsilane as a chloromethylation reagent, resulting in the formation of Chloromethylated Polysulfone (CMPS). CMPS was converted to a quaternized form using trimethylamine and precipitated into ethanol. The powder was dissolved in $\mathrm{N}$-methylpyrrolidone, followed by aminated with a $25 \mathrm{wt} \%$ trimethylamine. Results: The resulting solution was cast onto a flat glass plate and dried in an oven. The membrane was immersed in $\mathrm{KOH}$ solution for $24 \mathrm{~h}$ to replace the $\mathrm{Cl}^{-}$anion in the polymer with $\mathrm{OH}^{-}$. Conclusion: The swelling behavior of polysulfone-based solid-state alkaline electrolyte membrane was closely related to the degree of water uptake $(25 \mathrm{WU} \%, 7.5 \mathrm{SD} \%)$ and the ion-exchange capacity was 1.05 mmol g${ }^{-1}$, which is sufficient for electrolyte membranes used in alkaline fuel cells.
\end{abstract}

Key words: Alkaline electrolyte membrane, solid-state alkaline, polysulfone, simplified synthetic route

\section{INTRODUCTION}

Alkaline Fuel Cells (AFCs) are hydrogen-fuelled cells containing a liquid electrolyte (aqueous $\mathrm{KOH}$ solution) and show the best performance among all known fuel cells operating below $200^{\circ} \mathrm{C}$, mainly owing to facile kinetics at the cathode and anode and the use of cheap non-noble metal catalysts, such as nickel and silver (Mclean and Niet, 2002; Varcoe and Slade, 2005). However, their electrolyte is easily poisoned by $\mathrm{CO}_{2}$, which dramatically reduces their performance (Abuin et al., 2010). Solid-state polymer electrolytes with a less corrosive alkaline medium, such as a hydroxide anion exchange membrane, are alternatives to $\mathrm{KOH}$ solution. Anion Exchange Membranes (AEMs) are a key technology for achieving good particle performance in alkaline membrane fuel cells owing to their lower cost and higher durability as compared to those of commercial conducting polymers and proton exchange membranes. Currently, there is a growing interest in AEMs (Abuin et al., 2010; Asazawa et al., 2007; Bianchini et al., 2009; Fujiwara et al., 2008; Hou et al., 2008; Li et al., 2009; Lu et al., 2008; Matsumoto et al., 2011; Scott et al., 2008; Sleightholme et al., 2008; Tamain et al., 2007; Yang et al., 2008; Yang, 2007; Varcoe and Slade, 2005; Varcoe et al., 2007a; 2007b; Varcoe, 2007). The development of highperformance AEMs depends on the type of membrane materials, ionomers and synthetic methods used, namely, (a) polymers blended with alkaline media; (b) pyridinium-based polymers; (c) radiation-grafted and quaternized polymers; and (d) chloromethylated, quaternized and alkalized polymers. Many types of AEMs based on quaternized polymers have been developed, such as polysiloxane containing a quaternary ammonium group (Kang et al., 2004), 
poly(oxyethylene methacrylates) containing an ammonium group (Yi et al., 1999), quaternized polyethersulfone cardo (Li and Wang, 2005), quaternized poly (phthalazinone ethersulfone ketone) (Su et al., 2004) and radiation-grafted poly(vinyldidene fluoride) and poly(tetrafluoroethenehexafluoropropylene) (Danks et al., 2003). As a frequently used polymer-based engineering material, Polysulfone (PS) possesses excellent high-temperature creep resistance, high chemical and oxidative resistance and excellent electrical and mechanical properties. AEMs prepared via chloromethylated and quaternized routes are the most crucial because of their good physical and relatively high chemical stability. Chloromethylethylether was commonly used as a chloromethylating agent for providing excellent conversions and high product yields, but it is now considered to be carcinogenic and its use has been restricted since the 1940s (IARC, 1974; Laskin et al., 1971; Taylor and Laughlin, 1976). In our work, we used paraformaldehyde and chlorotrimethylsilane as chloromethylating agents and low toxicity solvents, such as N-Methylpyrrolidone (NMP) and ethanol, instead of N,N-dimethylformamide and methanol, respectively.

\section{MATERIALS AND METHODS}

All chemicals were purchased from Sigma-Aldrich and used without further purification. Quaternary Ammonium Polysulfone (QAPS) was synthesized in a two-step sequence (chloromethylation and quaternization), as shown in Fig. 1. The chloromethylation of PS was carried out in a three-neck round-bottom flask with a mechanical stirrer. PS (5 g) was dissolved in chloroform $(250 \mathrm{~mL})$. After adding stannic chloride $\left(\mathrm{SnCl}_{4}\right) \quad(0.27 \quad \mathrm{~mL})$ and paraformaldehyde $(6.792 \mathrm{~g})$ to the solution, chlorotrimethylsilane $(28.64 \mathrm{~mL})$ was added dropwise. The solution was stirred for $48 \mathrm{~h}$ at $55^{\circ} \mathrm{C}$. The Chloromethylated Polysulfone (CMPS) thus obtained was precipitated into ethanol, washed several times with deionized water and then dried in a vacuum oven for $12 \mathrm{~h}$ at $80^{\circ} \mathrm{C}$. Quaternization was carried out using the dried CMPS (1.88 g). The powder was dissolved in NMP (18.85 mL) and further aminated with a $25 \mathrm{wt} \%$ trimethylamine solution $(3.15 \mathrm{~mL})$ at $60^{\circ} \mathrm{C}$ for $15 \mathrm{~h}$ to obtain QAPS-Cl. The resulting QAPS-Cl solution was cast onto a clean, flat glass plate and dried in an oven at $70^{\circ} \mathrm{C}$ for $72 \mathrm{~h}$. The QAPS-Cl membrane was immersed in $\mathrm{KOH}$ solution $(1 \mathrm{M})$ for $24 \mathrm{~h}$ to replace the $\mathrm{Cl}^{-}$anion in the polymer with $\mathrm{OH}^{-}$. This process was repeated four times to ensure complete displacement. Finally, the OH-type QAPS (QAPS-OH) membrane was repeatedly rinsed with deionized water until the $\mathrm{pH}$ of the residual water was neutral. ${ }^{1} \mathrm{H} \mathrm{NMR}\left(300 \mathrm{MHz}, \mathrm{CDCl}_{3}\right.$ (PS and CMPS), DMSO-d $\mathrm{d}_{6}$ (QAPS-Cl and QAPS-OH), $25^{\circ} \mathrm{C}$, TMS) and FT-IR spectroscopies were used to confirm the AEM structure at each synthesis step. Because the quaternized polymer forms were not soluble in $\mathrm{CDCl}_{3}$, DMSO-d $_{6}$ was used as the solvent. Water uptake (WU\%) and Swelling Degree (SD\%) were estimated to determine the percentage of water uptake by the membrane and the Ion-Exchange Capacity (IEC) was determined by the back titration method.

\section{RESULTS}

The ${ }^{1} \mathrm{H}$ NMR spectra in Fig. 2 confirms the structure of PS, as follows (ppm): 6.9-7.9 (multi Hs on phenyl group) and $1.7\left(\mathrm{CH}_{3}\right)$. As shown in Fig. $2 \mathrm{~b}$, chloromethylation occurred at the activated aryl ring between the isopropyl and ether bonds, according to the integrated intensity of peak $9(\delta=4.6 \mathrm{ppm})\left(\mathrm{s}, 2 \mathrm{H}, \mathrm{CH}_{2}\right)$. Figure 3a shows peak $2(\delta=3.0 \mathrm{ppm})\left(\mathrm{s}, 9 \mathrm{H}, \mathrm{CH}_{3}\right)$, which clearly indicates the conversion of a chloromethyl group into a quaternary ammonium group. The intensity ratio of peak $1(\delta=4.6 \mathrm{ppm})\left(\mathrm{br}, 2 \mathrm{H}, \mathrm{CH}_{2}\right)$ to peak 2 was approximately $2: 9$, which closely matches the ratio of the number of $\mathrm{H}$ atoms on the original chloromethyl group to that on the newly attached quaternary ammonium group. This result also indicates that the conversion of the chloromethyl group into the quaternary ammonium group was nearly completed in the second step.

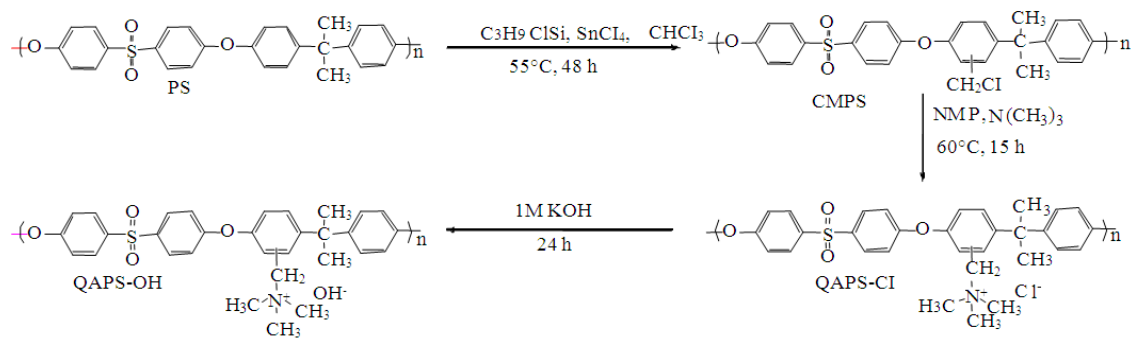

Fig. 1: Preparation of QAPS with $\mathrm{OH}$ - anions via chloromethylated intermediates 


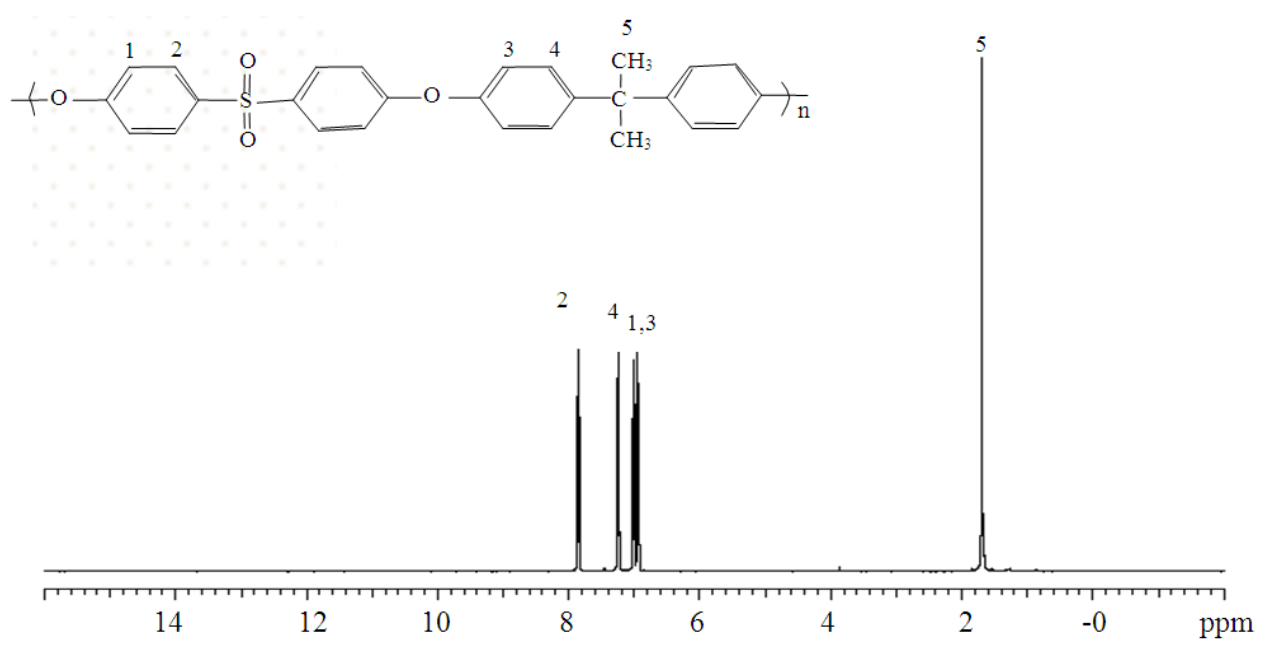

(a)
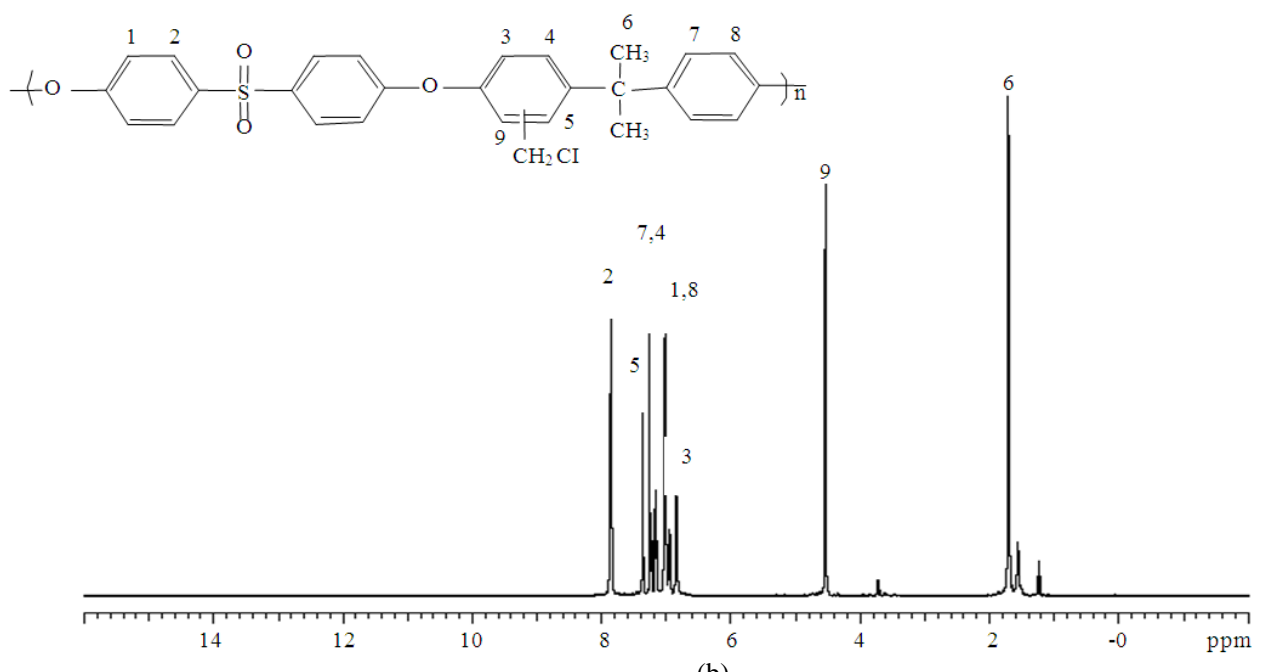

(b)

Fig. 2: ${ }^{1} \mathrm{H}$ NMR spectra of (a) PS and (b) CMPS in CDCl3

Figure $3 \mathrm{~b}$ shows the ${ }^{1} \mathrm{H}$ NMR spectra corresponding to the final product, QAPS-OH. In addition to the wellresolved peaks corresponding to $\mathrm{H}$ atoms on the QAPS chain, as shown in Fig. 3a and b, a split peak can be observed at $\delta=4.6 \mathrm{ppm}\left(\mathrm{d}, \mathrm{j}=27 \mathrm{~Hz}, 2 \mathrm{H}, \mathrm{CH}_{2}\right)$ and a new peak emerges at $\delta=5.9 \mathrm{ppm}\left(\mathrm{br}, \mathrm{w}, 1 \mathrm{H}, \mathrm{OH}^{-}\right)$, indicating that the $\mathrm{Cl}^{-}$anion has been successfully substituted by $\mathrm{OH}^{-}$anion, as shown in Fig. 3b.

The structure of the products was further confirmed by FT-IR analysis. As can be seen in Figure 4, the IR absorption band of PS clearly indicates the presence of the sulfonic group $(\mathrm{O}=\mathrm{S}=\mathrm{O})$ in the polymer back bond at 1149.5 and $1238.2 \mathrm{~cm}^{-1}$. The IR absorption bands at 1485.1 and $1585.4 \mathrm{~cm}^{-1}$ are characteristic of the phenyl group. A new characteristic peak with high intensity was observed at $1683.7 \mathrm{~cm}^{-1}$, corresponding to the aminated aromatic salts.

\section{DISCUSSION}

This confirms the successful introduction of ammonium groups into the polymer QAPS-Cl. Therefore, chloromethylation is the most important step in preparing AEMs; the chloromethylated polymer is readily modified further by the high reactivity of the tethered chloromethyl group. The membrane thickness was controlled at $125 \mu \mathrm{m}$ in the dry state. The membrane swelling behavior was closely related to the degree of water uptake ( $25 \mathrm{WU} \%$, $7.5 \mathrm{SD} \%$ ) and the IEC was $1.05 \mathrm{mmol} \mathrm{g}^{-1}$, which is sufficient for electrolyte membranes in AFCs. 
Am. J. Applied Sci., 9 (10): 1577-1582, 2012
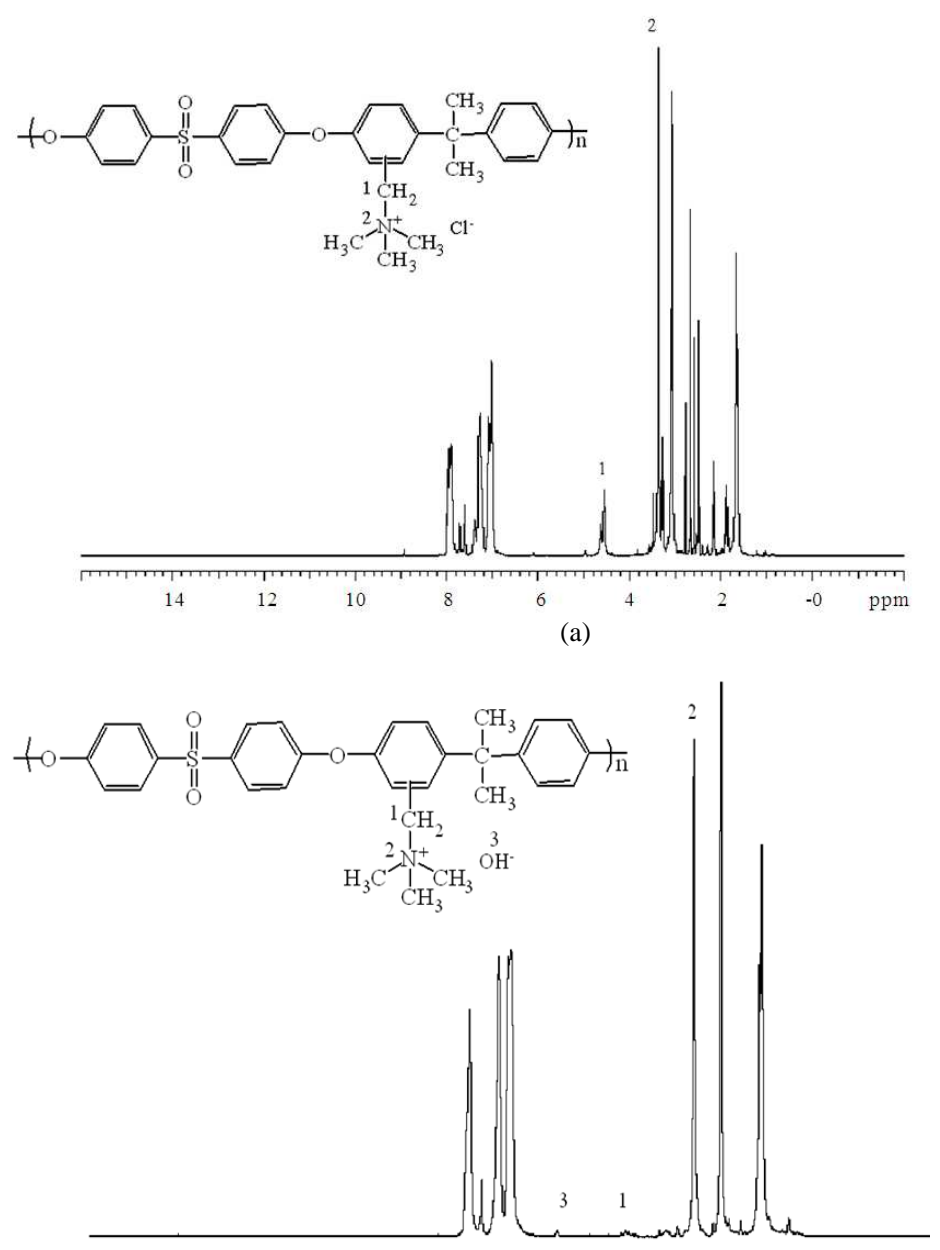

(b)

Fig. 3: ${ }^{1} \mathrm{H}$ NMR spectra of (a) QAPS-Cl and (b) QAPS-OH in DMSO-d6

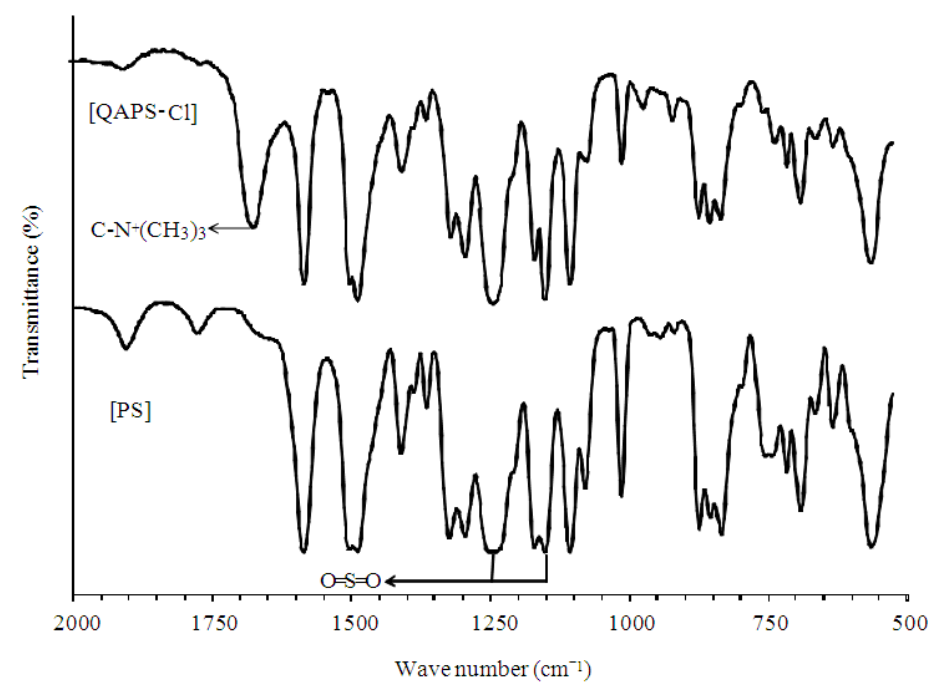

Fig. 4: FT-IR spectra of PS and QAPS-Cl 1580 
However, the polymer should be more physically and chemically characterized in terms of ion conductivity, thermal stability, solubility in water and alcohol for further applications as an electrolyte in AFCs.

\section{CONCLUSION}

In summary, this is a simplified synthetic route to quaternized PS using reagents of low carcinogenic toxicity. Quaternized PS was prepared by chloromethylation followed by quaternization using trimethylamine as an amination agent. Finally, alkalinization was carried out to transform the PS from the $\mathrm{Cl}^{-}$form to the $\mathrm{OH}^{-}$form using $1 \mathrm{M} \mathrm{KOH}$ solution.

\section{ACKNOWLEDGEMENT}

This study was financially supported by the Rajabhat Lampang University Fund under Grant No.003154 and was partly supported by the Center for Innovation in Chemistry (PERCH-CIC), Commission on Higher Education (CHE), Ministry of Education. We are very grateful for all the support.

\section{REFERENCES}

Abuin, G.C., P. Nonjola, E.A. Franceschini, F.H. Izraelevitch and M.K. Mathe et al., 2010. Characterization of an anionic-exchange membranes for direct methanol alkaline fuel cells. Int. J. Hydrogen. Energy, 35: 5849-5854. DOI: 10.1016/j.ijhydene.2009.12.128

Asazawa, K., K. Yamada, H. Tanaka, A. Oka and M. Taniguchi et al., 2007. A platinum-free zerocarbon emission easy fuelling direct hydrazine fuel cell for vehicles. Angew. Chem. Int. Ed., 46: 80248027. DOI: 10.1002/anie.200701334

Bianchini, C., V. Bambagioni, J. Filippi, A. Marchionni and F. Vizza et al., 2009. Selective oxidation of ethanol to acetic acid in highly efficient polymer electrolyte membrane-direct ethanol fuel cells. Electrochem. Commun., 11: 1077-1080. DOI: 10.1016/j.elecom.2009.03.022

Danks, T.N., R.C.T. Slade and J.R. Varcoe, 2003. Alkaline anion-exchange radiation-grafted membranes for possible electrochemical application in fuel cells. J. Mater. Chem., 13: 712721. DOI: 10.1039/B212164F

Fujiwara, N., Z. Siroma, S. Yamazaki, T. Ioroi, H. Senoh and K. Yasuda, 2008. Direct ethanol fuel cells using an anion exchange membrane. J. Power. Sources, 185: 621-626. DOI: 10.1016/j.jpowsour.2008.09.024
Hou, H.Y., G.Q. Sun, R.H. He, Z.M. Wu and B.Y. Sun, 2008. Alkali doped polybenzimidazolemembrane $\mathrm{f}$ or high performance alkaline direct ethanol fuel cel 1. J. Power Sources, 182: 95-99. DOI: 10.1016/j.jpowsour.2008.04.010

IARC, 1974. Some Aromatic Amines, Hydrazine and Related Substances, N-nitroso Compounds and Miscellaneous Alkylating Agents. 1st Edn., International Agency for Research on Cancer, Lyon, France, pp: 286.

Kang, J.J., W.Y. Li, Y. Lin, X.P. Li, X.R. Xiao and S. Fang, 2004. Synthesis and ionic conductivity of a polysiloxane containing quaternaryammonium groups. Polym. Adv. Technol., 15: 61-64. DOI: 10.1002/pat.434

Laskin, S., M. Kusschner, R.T. Drew, V.P. Capiello and N. Nelson, 1971. Tumors of the respiratory tract induce by inhalation of bis(chloromethyl) ether. Arch. Environ. Health, 23: 135-136.

Li, L. and Y. Wang, 2005. Quaternized polyethersulfone Cardo anion exchange membranes for direct methanol alkaline fuel cells. J. Membr. Sci., 262: 1-4. DOI: 10.1016/j.memsci.2005.07.009

Li, Y.S., T.S. Zhao and Z.X. Liang, 2009. Performance of alkaline electrolyte-membrane based direct ethanol fuel cells. J. Power. Sources, 187: 387-392. DOI: 10.1016/j.jpowsour.2008.10.132

Lu, S., J. Pan, A. Huang, L. Zhuang and J. Lu, 2008. Alkaline polymer electrolyte fuel cells completely free from noble metal catalysts. Proc. Natl. Acad. Sci. USA., 105: 20611-20614. DOI: 10.1073/pnas.0810041106

Matsumoto, K., T. Fujigaya, H. Yanagi and M. Nakashima, 2011. Very high performance alkaline exchange membrane fuel cells. Adv. Funct. Mater., 21: 1089-1094. DOI: 10.1002/adfm.201001806

Mclean, G.F., T. Niet, S. Prince-Richard and N. Djilali, 2002. An assessment of alkaline fuel cell technology. Int. J. Hydrogen. Energy, 27: 501-506. DOI: 10.1016/S0360-3199(01)00181-1

Scott, K., E. Yu, G. Vlachogiannopoulos, M. Shivare and N. Duteanu, 2008. Performance of a direct methanol alkaline membrane fuel cell. J. Power Sources, 175: 452-457. DOI: 10.1016/j.jpowsour.2007.09.027

Sleightholme, A.E.S., J.R. Varcoe and A. Kucernak, 2008. Oxygen reduction at the silver/hydroxideexchange membrane interface. Electrochem. Commun., 10: 151-155. DOI: 10.1016/j.elecom.2007.11.008 
Su, L., X. Jian, S. Zhang and G. Wang, 2004. Preparation and characterization of quaternized poly (phthalazinone ether sulfone ketone) NF membranes. J. Membr. Sci., 241: 225-233. DOI: 10.1016/j.memsci.2004.04.040

Tamain, C., S.D. Poynton, R.C.T. Slade, B. Carroll and J.R. Varcoe, 2007. Development of cathode architectures customized for $\mathrm{H}_{2} / \mathrm{O}_{2}$ metal-cationfree alkaline membrane fuel cells. J. Phys. Chem. C., 111: 18423-18430. DOI: 10.1021/jp076740c

Taylor, L.D. and P.M.C. Laughlin, 1976. Preparations and reactions of quanternary salts of bis (chloromethyl) ether. J. Applied Polym. Sci., 20: 2225-2228. DOI: 10.1002/app.1976.070200817

Varcoe, J.R. and R.C.T. Slade, 2005. Prospects for alkaline anion-exchange membranes in low temperature fuel cells. Fuel. Cells., 5: 187-200. DOI: $10.1002 /$ fuce. 200400045

Varcoe, J.R., 2007. Investigations of the ex situ ionic conductivities at $30^{\circ} \mathrm{C}$ of metal-cation-free quaternary ammonium alkaline anion-exchange membranes in static atmospheres of different relative humidities. Phys. Chem. Chem. Phys., 9: 1479-1486. DOI: 10.1039/B615478F

Varcoe, J.R., R.C.T. Slade, E.L.H. Yee, S.D. Poynton and D.J. Driscoll et al., 2007a. Poly (ethylene-co tetrafluoroethylene)-derived radiation-grafted anion-exchange membrane with properties specifically tailored for application in metalcation-free alkaline polymer electrolyte fuel cells. Chem. Mater., 19: 2686-2693. DOI: $10.1021 / \mathrm{cm} 062407 \mathrm{u}$
Varcoe, J.R., R.C.T. Slade, E.L.H. Yee, S.D. Poynton and D.J. Driscoll, 2007b. Investigations into the exsitu methanol, ethanol and ethylene glycol permeabilities of alkaline polymer electrolyte membranes. J. Power. Sources., 173: 194-199. DOI: 10.1016/j.jpowsour.2007.04.068

Yang, C.C., 2007. Synthesis and characterization of the cross-linked $\mathrm{PVA} / \mathrm{TiO}_{2}$ composite polymer membrane for alkaline DMFC. J. Membr. Sci., 288: 51-60. DOI: 10.1016/j.memsci.2006.10.048

Yang, C.C., S.J. Chiu, K.T. Lee, W.C. Chien and C.T. Lin et al., 2008. Study of poly (vinyl alcohol)/titanium oxide composite polymer membranes and their applicationon alkalin e direct alcoholfuel cell. J. Power. Sources., 184: 44-51. DOI: 10.1016/j.jpowsour.2008.06.011

Yi, F., X. Yang, Y. Li and S. Fang, 1999. Synthesis and ion conductivity of poly(oxyethylene) methacrylates containing a quaternary ammonium group. Polym. Adv. Technol., 10: 473-475. DOI: 10.1002/(SICI)1099-1581(199907)10:7<473::AIDPAT900>3.0.CO;2-2 